\title{
DOSIS HIJAUAN DAN MULSA PADA \\ PERTUMBUHAN DAN HASIL TANAMAN OKRA \\ (Abelmoschus esculentus L. Moench.)
}

\section{DOSAGE OF GREEN MANURE AND MULCHING IN GROWTH AND RESULTS OF OKRA PLANTS \\ (Abelmoschus esculentus L. Moench.)}

\author{
Palupi Puspitorini ${ }^{1)}$ \\ ${ }^{1)}$ Fakultas Pertanian, Universitas Islam Balitar Blitar \\ Email: puspitorini.palupi@gmail.com
}

\begin{abstract}
ABSTRAK
Tujuan dari penelitian ini adalah 1), menentukan dosis Tithonia optimal dan perlakuan mulsa jerami pada tanaman okra, 2) membandingkan pemupukan Tithonia organik dan anorganik, 3). untuk menentukan sisa nutrisi dalam tanah setelah panen okra. Percobaan disusun dalam rancangan petak faktorial. Petak utama adalah mulsa jerami terdiri 2 tingkat ( 0 dan 5 tonha-1). Anak petak adalah Tithonia terdiri dari 6 tingkat $(0,60,120,180,240 \mathrm{~kg}$ Nha-1 dan 120 kgha-1 pupuk anorganik sebagai kontrol. Tanah memiliki C organik $1,47 \%$ (rendah), total tanah $\mathrm{N} \mathrm{0,2 \%}$ (sedang), rasio $\mathrm{C} / \mathrm{N}$ 6,0 (rendah), $\mathrm{K}_{2} \mathrm{O} 48$ me100 gr-1 (tinggi) dan $\mathrm{P}_{2} \mathrm{O}_{5}$ (olsen) 27,64 mgkg-1 (sedang), kandungan bahan organik 2,53\% (sedang). adalah tinggi tanaman, jumlah daun, luas daun dan berat kering total tanaman. Hasil penelitian ini adalah tidak terdapat interaksi dosis Tithonia dan mulsa jerami. Pertumbuhan dan hasil okra dipengaruhi secara signifikan oleh tingkat Tithonia. Mulsa jerami sangat penting dibandingkan tanpa perlakuan mulsa. Perlakuan pemupukan meningkatkan $25 \%$ dari rata-rata hasil polong segar dibandingkan tanpa pemupukan. Pertumbuhan dan hasil okra terbaik adalah dengan pemupukan Tithonia 180 kgNha-1. Bobot kering total tanaman 90-200\% lebih tinggi daripada tanpa pemupukan. Pemupukan anorganik meningkatkan $36 \%$ berat segar polong dari pemupukan organik. Mulsa jerami memiliki efek negatif terhadap okra pada musim hujan, penurunan jumlah polong segar masing-masing $26-48 \%$, hasil okra polong segar berkurang 57-98\%. Kadar polong dan kadar gula total polong tidak dipengaruhi oleh tingkat Tithonia dan mulsa jerami.
\end{abstract}

Kata kunci: bahan organik sedang; mulsa jerami; okra; Tithonia

\begin{abstract}
The objective of this study was to determine of optimal Tithonia rate on straw mulching treatment of okra, comparing of inorganic and organic Tithonia fertilizing, to determine of soil nutrition remaining after okra harvest.The treatment were factorial split plot design. Straw mulching was a main plot of 2 rates ( 0 and 5 tonha-1). Thitonia was a subplot of 6 rates $(0,60,120,180,240 \mathrm{~kg}$ $\mathrm{Nha}^{-1}$ and $120 \mathrm{kgha-1}$ anorganic fertilizer as a control. The soil had $C$ organik of $1.47 \%$ (low), total soil $\mathrm{N}$ of $0.2 \%$ (medium), $\mathrm{C} / \mathrm{N}$ ratio of 6.0 (low), $\mathrm{K}_{2} \mathrm{O}$ of 48 melo0 $\mathrm{gr}^{-1}$ (high) and $\mathrm{P}_{2} \mathrm{O}_{5}$ (olsen) of $27.64 \mathrm{mgkg}-1$ (medium), organic matter content of $2.53 \%$ (medium). Variable taking were plant heigh, leaf count, total plant dry weigh, leaf area. Result of this experiment were no interaction of
\end{abstract}


Tithonia rate and straw mulching treatment. Growth and yield of okra were influenced significantly by Tithonia rate. Straw mulching was significance comparing no mulch treatment. Fertilizing treatment increased $25 \%$ of average pods fresh yield comparing no fertilizing. Growth and yield the best value of Tithonia was $180 \mathrm{kgNha}-1$ respectively. Average of fertilizing treatment total plant dry weight were 90-200\% higher than no fertilizing treatment. Inorganic fertilizing increased of $36 \%$ pods fresh weight than organic fertilizing. Straw mulching have negative effect to okra on rainy season, decreasing fresh pods count 26-48\% respectively, okra pods fresh yield decrease 57-98\%. Pods grade and pods total sugar content were not influenced significance by Tithonia rate and straw mulching.

Keywords: medium organic matter, okra fertilizing; straw mulch; Tithonia

\section{PENDAHULUAN}

Okra mempunyai nilai ekonomi yang tinggi. Prospek okra terus meningkat baik di Asia (Jepang, Korea, Malaysia) dan di Amerika Serikat. Menurut Yulliartini, et al. (2018) konsumsi okra di Amerika Serikat meningkat dari tahun 2000 hingga 2014 mencapai 30 juta lbs (13.600 ton). Peningkatan konsumsi okra juga diikuti dengan peningkatan harga dari US\$ $2.28 \mathrm{~kg}^{-1}$ menjadi US\$ $2.43 \mathrm{~kg}^{-1}$.

Menurut Zulkarnain, et al. (2013), penggunaan pupuk sintetis menyebabkan tingginya biaya produksi tanaman, pencemaran lingkungan dan menurunnya kesehatan masyarakat akibat makanan yang tidak sehat, peningkatan tingkat kemasaman tanah yang akan berdampak negatif untuk lingkungan dalam jangka panjang. Maka sangat dibutuhkan sistem terpadu untuk pengelolaan tanah sebagai tempat tumbuh tanaman dan penyedia hara bagi tanaman (Berek, 2017).

$$
\text { Bahan organik berfungsi }
$$
sebagai pemasok hara, penyangga air tanah, memperbaiki struktur tanah (Zulkarnain, et al., 2013). Bahan organik juga mengaktifkan biofauna tanah yang semuanya akan mendukung perbaikan sifat tanah dalam jangka panjang dan berkelanjutan (Afandi, et al., 2015).

Hasil penelitian bahan organik Tithonia dengan dosis setara 165 $\mathrm{kgNha}^{-1}$ yang diberikan secara sendiri dapat meningkatkan produksi jagung lebih tinggi $16 \%$ dari 3,6 menjadi 4,3 tonha $^{-1}$ dibandingkan pemupukan anorganik dengan dosis $165 \mathrm{kgNha}^{-1}$. Aplikasi bahan organik Tithonia telah terbukti meningkatkan produktivitas berbagai tanaman. Pemberian 
Tithonia dengan dosis $175 \mathrm{kgNha}^{-1}$ memberikan bobot umbi kentang 30 ton $\mathrm{ha}^{-1}$ yang tidak berbeda dibandingkan pemupukan anorganik pada dosis $175 \mathrm{kgNha}^{-1}$ (Dewanti, 2005). Penelitian pada tanaman jagung manis didapatkan bahwa dosis Tithonia 6 tonha $^{-1}$ (setara $138 \mathrm{kgNha}^{-}$ 1) memberikan hasil 8 tonha-1 bobot segar tongkol. Penelitian tentang pemulsaan organik pada tanaman jagung oleh Tian, et al. (1993) dengan mulsa jerami yang dilakukan pada musim penghujan diperoleh data bahwa pemulsaan jerami dapat menurunkan rata rata suhu tanah dari $28,4^{\circ} \mathrm{C}$ menjadi $27,5^{\circ} \mathrm{C}$ dan menurunkan laju dekomposisi beberapa bahan organik.

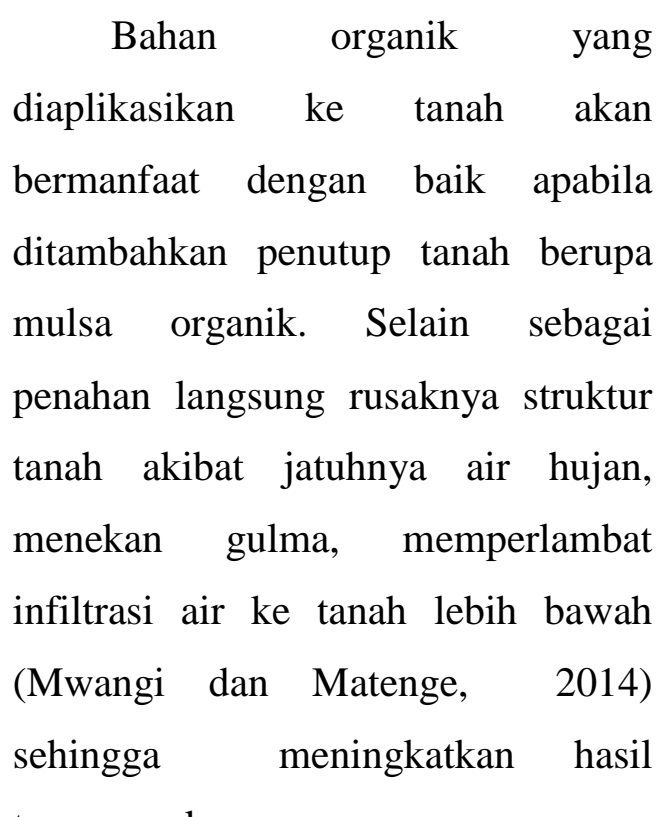
tanaman okra.

Pemberian bahan organik ke tanah lebih efektif diberikan pada tanah berbahan organik rendah dibandingkan pada tanah berbahan organik sedang atau tinggi disebabkan karena kandungan mineral liat yang lebih tinggi di tanah berbahan organik rendah. Menurut Utami, et al. (2005) efektivitas tersebut diukur dengan penurunan $\mathrm{P}$ terjerap pada tanah dengan bahan organik rendah yang mempunyai mineral amorf $9 \%$ lebih tinggi dibandingkan pada tanah berbahan organik tinggi. Demikian juga terjadi peningkatan $\mathrm{pH} 0.12$ poin pada BOT rendah sedangkan pada BOT tinggi 0.07 poin.

Tujuan penelitian ini adalah menentukan kombinasi dosis bahan organik Tithonia optimal pada perlakuan pemberian mulsa untuk memperoleh hasil maksimal tanaman okra baik untuk konsumsi maupun obat. Juga untuk membandingkan pertumbuhan dan hasil tanaman okra pada pemberian pupuk organik dan anorganik pada tingkat $\mathrm{N}$ yang sama dan mendapatkan potensi unsur hara tertinggal dalam tanah setelah panen okra pada berbagai tingkat dosis Tithonia dan perlakuan pemulsaan.

\section{METODOLOGI PENELITIAN}

Penelitian dilaksanakan di Singosari Malang dengan ketinggian 
tempat kurang lebih 480 meter di atas permukaan laut. Jenis tanah pada lokasi percobaan ialah inseptisol. Status tanah pada lokasi percobaan adalah C organik $1.47 \%$ (rendah), N tanah $0.2 \%$ (sedang), bahan organik 2.54 (sedang), $\mathrm{C} / \mathrm{N}$ ratio 6.0 (rendah), $\mathrm{K}_{2} \mathrm{O} 48$ me100 gr $^{-1}$ (tinggi) dan $\mathrm{P}_{2} \mathrm{O}_{5}$ (olsen) $27.64 \mathrm{mg} / \mathrm{kg}$ (sedang) dan $\mathrm{pH} 5.5$.

Bahan yang digunakan adalah benih okra Varietas Ari Fife ex Jepang, bahan organik Tithonia (Tithonia diversifolia), pupuk NPK $15: 15: 15$ dan ZA (untuk perlakuan anorganik). Alat leaf area meter, termometer suhu tanah, timbangan elektrik dan oven.

Percobaan dilakukan di lapang menggunakan rancangan acak kelompok (RAK) dalam petak terbagi faktorial 2 faktor dengan 3 kali ulangan. Sebagai petak utama (PU) ialah pemulsaan jerami padi terdiri 2 aras. Sedangkan anak petak (AP) ialah dosis Tithonia yang terdiri dari 6 aras. Petak utama (PU): pemulsaan jerami padi; P1 = tanpa pemulsaan; $\mathrm{P} 2=$ pemulsaan jerami padi 5 ton/ha. Anak petak (AP): pemupukan; $\mathrm{T} 0=$ tanpa pemupukan, $\mathrm{T} 1=$ Tithonia setara $60 \mathrm{~kg} \mathrm{~N} / \mathrm{ha}, \mathrm{T} 2=$ Tithonia setara $120 \mathrm{~kg} \mathrm{~N} / \mathrm{ha}, \mathrm{T} 3$ = pemupukan anorganik rekomendasi dengan $\mathrm{N}$ setara $120 \mathrm{~kg} \mathrm{~N} / \mathrm{ha}, \mathrm{T} 4=$ Tithonia setara $180 \mathrm{~kg} / \mathrm{ha}, \mathrm{T} 5=$ Tithonia setara 240 kg/ha. Pengamatan dilakukan terhadap tanah (soil test), tanaman (plant analysis) dan kualitas buah. Variabel pendukung analisis kimia tanah dilakukan pada awal tanam, umur 60 HST dan setelah panen okra. Analisis tanah sebelum tanam meliputi $\mathrm{pH}, \mathrm{C}$ - organik, $\mathrm{N}$ total, $\mathrm{NH}_{4}{ }^{+}, \mathrm{NO}_{3}{ }^{-}, \mathrm{P}, \mathrm{K}$, umur 60 HST meliputi $\mathrm{pH}, \mathrm{C}$-organik, $\mathrm{N}$ total, $\mathrm{NH}_{4}^{+}, \mathrm{NO}_{3}^{-}, \mathrm{P}, \mathrm{K}$. Setelah panen tanam meliputi $\mathrm{pH}, \mathrm{C}$-organik, $\mathrm{N}$ total, $\mathrm{NH}_{4}^{+}, \mathrm{NO}_{3}^{-}, \mathrm{P}, \mathrm{K}$. Analisis bahan organik sebelum aplikasi meliputi C-organik, $\mathrm{N}$ total, $\mathrm{P}, \mathrm{K}$. Analisis serapan tanaman okra umur 60 HST yaitu serapan N, P, K. Pengamatan pertumbuhan dilakukan pada variabel tinggi tanaman pada 20, 40, 60,80, 100 HST, luas daun (LA) okra pada 20, 40, 60,80, 100 hari setelah tanam dengan metode leaf area meter. Bobot kering tanaman okra umur 20, 40, 60,80, 100 hari setelah tanam, jumlah total polong okra/tanaman saat panen, bobot polong okra/tanaman saat panen, hasil polong okra/hektar saat panen. Pengkelasan okra berdasarkan ukuran fisik saat panen, kadar gula polong 
saat panen, suhu tanah pada 20,40 , 60 HST. Parameter yang dihitung ialah LAI (leaf area indeks), CGR (crop growth rate), NAR (net assimilation ratio) (Agustina, 2004), recovery nutrisi (Gachengo, et al., 1999).

Data dianalisis dengan menggunakan analisis ragam dengan taraf signifikansi $5 \%$. Perbedaan antar perlakuan organik dan anorganik menggunakan uji Duncans.

\section{HASIL DAN PEMBAHASAN}

\section{Peubah Pertumbuhan Tanaman Okra}

Hasil analisis ragam tinggi tanaman menunjukkan tidak ada interaksi nyata antara pemulsaan jerami padi dan dosis Tithonia selama pertumbuhan tanaman. Uji orthogonal memperlihatkan bahwa pemupukan memberikan peningkatan rata-rata tinggi tanaman 15-26\% dibandingkan tanpa pemberian pupuk. Dosis Tithonia 180 tonha $^{-1}$ memberikan hasil rata-rata tinggi tanaman $7-15 \%$ lebih tinggi dibandingkan dosis Tithonia yang lain. Pemberian pupuk anorganik memberikan rata-rata tinggi tanaman 42-46\% lebih tinggi dibandingkan pupuk organik. Uji beda nyata DMRT 5\% untuk pemulsaan jerami padi menurunkan rata-rata tinggi tanaman hingga 14\% dibandingkan tanpa pemulsaan jerami padi (Tabel 1). Hasil analisis ragam jumlah daun menunjukkan tidak ada interaksi nyata antara pemulsaan jerami padi dan dosis Tithonia pada semua umur pengamatan. Uji orthogonal pada perlakuan pemupukan memberikan peningkatan rata-rata jumlah daun $17-20 \%$ dibandingkan tanpa pemberian pupuk pada umur 80 hingga 100 hari setelah tanam (HST). Pemberian pupuk anorganik memberikan rata-rata jumlah daun 10-20 \% lebih banyak dibandingkan pupuk organik. Pemberian bahan organik Tithonia memberikan rata-rata jumlah daun tanaman 6-9\% lebih banyak dibandingkan dosis Tithonia lainnya. Pemulsaan jerami padi pada tanaman okra menurunkan rata-rata jumlah daun 12-14\% dibandingkan tanpa mulsa. Pemulsaan jerami padi dan pemberian dosis Tithonia menunjukkan hasil interaksi yang tidak nyata pada analisis ragam $(5 \%)$ selama pertumbuhan tanaman untuk variabel luas daun (Tabel 1). Pemupukan memberikan peningkatan rata-rata luas daun 90-200 \% dibandingkan tanpa pupuk. 
Sedangkan pemberian pupuk anorganik memberikan rata-rata luas daun 46-97 \% lebih banyak dibandingkan pupuk organik. Luas daun tertinggi didapat pada aplikasi Tithonia dengan dosis 180 tonha $^{-1}$ yaitu $27-47 \%$ dibandingkan dosis Tithonia lainnya. Pemulsaan jerami memberikan hasil luas daun tanaman 6-9\% lebih banyak dibandingkan dosis Tithonia lainnya (Tabel 1).

Tidak terdapat interaksi nyata antara pemulsaan jerami padi dan dosis Tithonia hingga akhir masa pertumbuhan tanaman okra. Pada indeks luas daun, pemupukan meningkatkan rata-rata indeks luas daun $50 \%$. Rata-rata indeks luas daun berkurang $30 \%$ dibandingkan tanpa mulsa. Analisis ragam bobot kering total tanaman di atas tanah (BKTA) menunjukkan tidak ada interaksi nyata antara pemulsaan jerami padi dan dosis Tithonia selama pertumbuhan tanaman. Pemupukan meneningkatkan rata-rata bobot kering total tanaman 90-200\% dibandingkan tanpa pupuk. Pemberian pupuk anorganik meningkatkan rata-rata BKTA 85$152 \%$ dibandingkan pupuk organik. Dosis Tithonia menunjukkan perbedaan nyata pada BKTA antar dosis Tithonia. Dosis Tithonia 180 tonha $^{-1}$ memberikan hasil terbaik yaitu 9-50 \% dibandingkan dosis Tithonia lainnya.

Tabel 1. Tinggi Tanaman, Luas Daun, Bobot Kering Total Tanaman Atas, Jumlah Daun pada Perlakuan Mulsa dan Dosis Tithonia

\begin{tabular}{|c|c|c|c|c|c|c|c|c|}
\hline \multirow{2}{*}{$\begin{array}{l}\text { Perlakuan } \\
\text { Dosis Tithonia }\end{array}$} & \multicolumn{2}{|c|}{$\begin{array}{l}\text { Tinggi } \\
\text { Tanaman } \\
(\mathrm{cm})\end{array}$} & \multicolumn{2}{|c|}{$\begin{array}{l}\text { Luas Daun } \\
\left(\mathrm{cm}^{2} \tan ^{-1}\right)\end{array}$} & \multicolumn{2}{|c|}{$\begin{array}{l}\text { BKTA } \\
\left(\operatorname{grtan}^{-1}\right)\end{array}$} & \multicolumn{2}{|c|}{$\begin{array}{l}\text { Jumlah } \\
\text { Daun }\end{array}$} \\
\hline & & & & & & & & \\
\hline T0 (tanpa Tithonia) & 107.2 & $\mathrm{a}$ & 567.06 & $\mathrm{a}$ & 17.94 & $\mathrm{a}$ & 14.89 & $\mathrm{a}$ \\
\hline T1 (Tithonia dosis 60 kgNha-1) & 111.2 & $a b$ & 924.24 & $\mathrm{~b}$ & 24.58 & $\mathrm{a}$ & 16.33 & $a b$ \\
\hline T2 (Tithonia dosis $120 \mathrm{kgNha}-1$ ) & 114.6 & $\mathrm{ab}$ & 982.30 & $\mathrm{~b}$ & 36.14 & $\mathrm{~b}$ & 16.16 & $\mathrm{ab}$ \\
\hline T4 (Tithonia dosis 180 kgNha-1) & 128.6 & $\mathrm{~b}$ & 1368.85 & c & 52.71 & $\mathrm{~cd}$ & 15.52 & $a b$ \\
\hline \multicolumn{9}{|l|}{ T5 (Tithonia dosis 240 kgNha-1) } \\
\hline & 118.6 & $\mathrm{ab}$ & 869.47 & b & 47.53 & bc & 17.48 & $\mathrm{~b}$ \\
\hline T3 (anorganik) & 165.9 & $\mathrm{c}$ & 1436.36 & d & 67.09 & $\mathrm{e}$ & 24.30 & $\mathrm{c}$ \\
\hline \multicolumn{9}{|l|}{ Pemulsaan } \\
\hline tanpa mulsa & 211.45 & $\mathrm{~b}$ & 1935.99 & b & 73.06 & $b$ & 29.52 & $\mathrm{~b}$ \\
\hline mulsa 5 tonha $^{-1}$ & 161.61 & $\mathrm{a}$ & 1313.66 & $\mathrm{a}$ & 49.94 & $\mathrm{a}$ & 24.37 & $\mathrm{a}$ \\
\hline
\end{tabular}

Keterangan:

BKTA: Bobot kering total atas tanah orthogonal kontras, perbedaaan antar perlakuan pemupukan organik diuji dengan menggunakan uji DMRT dengan $\alpha=5 \%$. 
Pemulsaan jerami padi menurunkan rata-rata bobot kering total tanaman okra 57-98\% dibandingkan tanpa mulsa. Pemulsaan menurunkan laju pertumbuhan tanaman $52 \%$ dibandingkan tanpa pemberian mulsa. Sedangkan perlakuan dosis Tithonia 180 tonha $^{-1}$ mempengaruhi secara nyata laju pertumbuhan tanaman umur 40 hingga 100 HST dengan nilai $62 \%$ lebih tinggi dibandingkan dosis yang lain.

\section{Peubah Hasil Tanaman Okra}

Hasil analisis ragam jumlah total polong/tanaman dan jumlah total polong/hektar menunjukkan tidak ada interaksi nyata antara pemulsaan jerami padi dan dosis Tithonia selama pertumbuhan tanaman. Pemulsaan menurunkan nilai rata-rata jumlah total polong/hektar dan bobot segar polong masing masing $26 \%$ dan $48 \%$ dibandingkan tanpa pemberian mulsa (Tabel 2). Perlakuan pemupukan dari uji orthogonal memberikan hasil jumlah total polong $25 \%$ lebih tinggi dibanding tanpa pemupukan, dan $41 \%$ lebih tinggi untuk bobot segar polong (Tabel 2). Perlakuan pemberian pupuk organik Tithonia memberikan hasil 50-60\% lebih rendah dibandingkan perlakuan pupuk anorganik untuk variabel jumlah polong/hektar. Uji BNT 5\% menunjukkan bahwa pemberian bahan organik Tithonia yang terbaik adalah 180 tonha $^{-1}$ dengan nilai 20$33 \%$ dibandingkan dosis yang lain. Hasil analisis ragam ukuran (pengkelasan) polong memberikan interaksi tidak nyata antara perlakuan pemulsaan jerami padi dan perlakuan dosis Tithonia. Pemulsaan jerami tidak berpengaruh nyata pada ukuran polong, demikian pula dosis Tithonia. Dari hasil analisis regresi pada total kandungan gula polong okra menunjukkan bahwa nilai koefisien determinasi $\mathrm{R}^{2}$ adalah 0,1895 yang mengindikasikan bahwa dosis bahan organik hanya dapat dijelaskan pengaruhnya pada kadar gula polong sebesar $18 \%$. 
Tabel 2. Bobot Polong dan Jumlah Polong Okra pada Dosis Tithonia dan Pemulsaan Jerami Padi

\begin{tabular}{|c|c|c|c|c|c|c|c|c|c|c|}
\hline \multirow{4}{*}{$\begin{array}{c}\text { Perlakuan } \\
\text { Tanpa Pemupukan (TP) }\end{array}$} & \multicolumn{10}{|c|}{ Total Panen pada Akhir Pengamatan (100 HST) } \\
\hline & \multicolumn{4}{|c|}{ Jumlah Polong Total } & \multicolumn{6}{|c|}{ Bobot Polong Total } \\
\hline & \multicolumn{2}{|c|}{$\tan -1$} & \multicolumn{2}{|l|}{ ha-1 } & \multicolumn{2}{|c|}{ gr $\tan ^{-1}$} & \multicolumn{2}{|c|}{ gr $\mathrm{m}^{-1}$} & \multicolumn{2}{|c|}{ ton $\mathrm{ha}^{-1}$} \\
\hline & 14.41 & a & $514,550.26$ & $\mathrm{a}$ & 112.66 & $\mathrm{a}$ & 402.34 & a & 28.16 & $\overline{\mathrm{a}}$ \\
\hline Pemupukan(P) & 18.03 & $\mathrm{~b}$ & $643,915.34$ & $\mathrm{~b}$ & 318.19 & $\mathrm{~b}$ & $1,136.40$ & $\mathrm{~b}$ & 79.55 & $\mathrm{~b}$ \\
\hline Orthogonal & $\mathrm{n}$ & & $\mathrm{n}$ & & $\mathrm{n}$ & & $\mathrm{n}$ & & $\mathrm{n}$ & \\
\hline Organik Tithonia $(\mathrm{T})$ & 14.78 & a & $527,777.78$ & $\mathrm{a}$ & 285.36 & $\mathrm{a}$ & $1,019.13$ & $\mathrm{a}$ & 71.34 & a \\
\hline Anorganik (A) & 23.85 & $\mathrm{~b}$ & $851,851.85$ & $\mathrm{~b}$ & 449.54 & $\mathrm{~b}$ & $1,605.49$ & $\mathrm{~b}$ & 112.38 & $\mathrm{~b}$ \\
\hline Orthogonal & $\mathrm{n}$ & & $\mathrm{n}$ & & $\mathrm{n}$ & & $\mathrm{n}$ & & $\mathrm{n}$ & \\
\hline \multicolumn{11}{|l|}{ Pemulsaan } \\
\hline Tanpa Mulsa & 29.19 & $\mathrm{~b}$ & $1,042,328.04$ & $\mathrm{~b}$ & 517.58 & $\mathrm{~b}$ & $2,301.59$ & $\mathrm{~b}$ & 35.70 & $\mathrm{~b}$ \\
\hline Mulsa 5 ton $\mathrm{ha}^{-1}$ & 23.09 & $\mathrm{a}$ & $824,735.45$ & $\mathrm{a}$ & 344.23 & a & $1,765.87$ & a & 24.10 & a \\
\hline BNT 5\% & 4.21 & & $150,638.52$ & & 31.13 & & 111.18 & & 7.78 & \\
\hline \multicolumn{11}{|l|}{ Dosis Tithonia } \\
\hline Tanpa Tithonia & 14.41 & $\mathrm{a}$ & $514,550.26$ & $\mathrm{a}$ & 112.66 & $\mathrm{a}$ & 402.34 & $\mathrm{a}$ & 28.16 & $\mathrm{a}$ \\
\hline Tithonia setara 60 ton ha ${ }^{-1}$ & 15.48 & a & $552,910.05$ & a & 231.40 & a & 826.44 & a & 57.85 & a \\
\hline $\begin{array}{l}\text { Tithonia setara } 120 \text { ton } \\
\text { ha }^{-1}\end{array}$ & 14.78 & $\mathrm{a}$ & $527,777.78$ & a & 287.22 & a & $1,025.79$ & $\mathrm{a}$ & 71.81 & $\mathrm{a}$ \\
\hline $\begin{array}{l}\text { Tithonia setara } 180 \text { ton } \\
\text { ha }^{-1}\end{array}$ & 21.00 & $\mathrm{~b}$ & $750,000.00$ & $\mathrm{~b}$ & 346.96 & $\mathrm{~b}$ & $1,239.15$ & $\mathrm{~b}$ & 86.74 & $\mathrm{~b}$ \\
\hline $\begin{array}{l}\text { Tithonia setara } 240 \text { ton } \\
\text { ha }^{-1}\end{array}$ & 15.04 & $\mathrm{a}$ & $537,037.04$ & $\mathrm{a}$ & 275.84 & $\mathrm{a}$ & 985.13 & $\mathrm{a}$ & 68.96 & $\mathrm{a}$ \\
\hline DMRT 5\% & 0.01 & & $36,136.78$ & & 23.94 & & 85.49 & & 5.98 & \\
\hline
\end{tabular}

Hasil analisis daun okra umur 60 HST (masa pertumbuhan cepat) mempunyai kecenderungan sama pada serapan nutrisi $\mathrm{N}, \mathrm{P}$ dan $\mathrm{K}$. Serapan tertinggi nutrisi N, P dan K terjadi pada perlakuan pupuk anorganik $120 \mathrm{~kg} \mathrm{Nha}^{-1}$, baik pada perlakuan pemulsaan ataupun tanpa pemberian mulsa. Pada perlakuan pemulsaan untuk dosis $\mathrm{N}$ yang sama $120 \mathrm{kgNha}^{-1}$ bahwa pupuk organik memberikan serapan N 55\% lebih rendah dibandingkan pupuk anorganik. Demikian pula serapan $\mathrm{P}$
$6 \%$ lebih rendah dan $\mathrm{K} 46 \%$ lebih rendah pada pupuk organik dibandingkan pupuk anorganik Perlakuan tanpa pemulsaan memberikan serapan N 77\%, P 54\% dan K $66 \%$ lebih rendah dibandingkan pemberian pupuk anorganik pada dosis $\mathrm{N}$ sama 120 $\mathrm{kgNha}^{-1}$. 
Pertumbuhan dan Hasil Tanaman
Okra pada
Pemupukan Perlakuan
Pemupukan

Pemupukan menambah ratarata tinggi tanaman 15-26\% dibandingkan tanpa pemupukan. Demikian pula rata-rata jumlah daun meningkat pada umur 80-100 HST hingga 17-20\%. Pemupukan memberikan hasil indeks luas daun tanaman $135 \%$ lebih tinggi. Peningkatan pertumbuhan ini disebabkan adanya perubahan kesuburan tanah diantaranya adanya peningkatan kandungan bahan organik tanah (5-10\%), peningkatan $74 \% \mathrm{~N}$ mineral tanah, peningkatan kandungan $\mathrm{P}$ tanah sebesar $21 \%$ dan peningkatan kandungan $\mathrm{K}$ tanah sebesar $16 \%$.

\section{Pertumbuhan dan Hasil Tanaman Okra pada Perlakuan Pemupukan Organik dan Anorganik}

Hasil penelitian menunjukkan adanya perbedaan yang nyata antara perlakuan pemupukan organik Tithonia dengan pupuk anorganik. Perlakuan pupuk anorganik pada tanaman okra memberikan rata rata tinggi tanaman $15-26 \%$ lebih tinggi dibandingkan pemupukan Tithonia.
Jumlah daun pada perlakuan pemupukan anorganik lebih tinggi 10-20\% dibanding organik. Demikian pula perlakuan pemupukan anorganik menghasilkan rata-rata luas daun 46-97\% lebih tinggi dibanding pemupukan organik Tithonia. Bobot kering total tanaman 85-152\% lebih tinggi pada pemupukan anorganik.

Pada hasil panen bahwa pemupukan anorganik memberikan bobot polong segar 36\% lebih tinggi dibandingkan pemupukan organik (Tabel 2). Pemberian Tithonia ke dalam tanah mempunyai banyak faktor yang mempengaruhi dalam proses dekomposisi hingga mineralisasi menjadi suatu komponen unsur yang siap diserap tanaman yaitu $\mathrm{NH}_{4}^{+}$dan $\mathrm{NO}_{3}^{-}$. Sedangkan pupuk anorganik bisa langsung terurai menjadi unsur yang siap diserap tanaman dalam waktu yang lebih cepat setelah pemberiannya ke dalam tanah.

Pemberian bahan organik pada tanah dengan kandungan bahan organik tinggi (kandungan BOT lahan penelitian 2,54\%) tidak seefektif pemberian bahan organik pada tanah dengan bahan organik rendah. Disampaikan oleh Palm, et 
al. (1997) bahwa ada hubungan erat antara input bahan organik, kandungan bahan organik tanah dan produksi tanaman. Pengaruh Tithonia lebih efektif pada tanah dengan bahan organik rendah dibandingkan pada tanah dengan bahan organik tinggi (Utami, et al., 2005). Efektivitas ini diukur dengan peningkatan $\mathrm{P}$ organik labil pada tanah dengan bahan organik rendah yang mempunyai persentase mineral amorf lebih tinggi (masif).

Lebih lanjut Utami, et al. (2005) menyatakan bahwa terjadi pula peningkatan $\mathrm{pH}$ yang lebih tinggi pada aplikasi Tithonia untuk tanah dengan bahan organik rendah dimana $\mathrm{pH}$ sangat berpengaruh pada proses dekomposisi bahan organik. Pada tanah dengan bahan organik tinggi peningkatan $\mathrm{pH}$ akibat Tithonia sebesar 0,07 poin sedangkan pada tanah dengan bahan organik rendah peningkatan $\mathrm{pH}$ sebesar 0,12 poin.

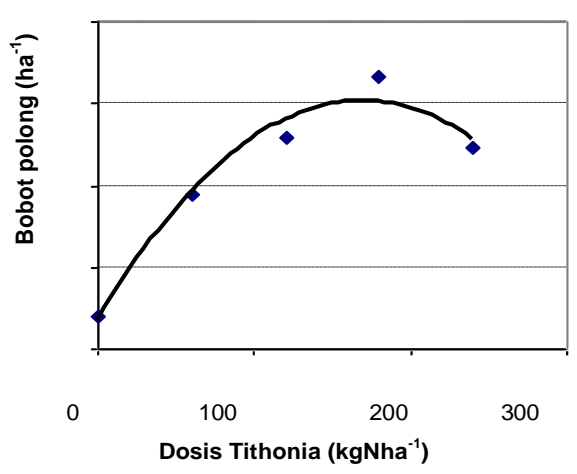

Gambar 4. Optimal Dosis Tithonia pada Okra

\section{Pertumbuhan dan Hasil Tanaman Okra Antar Dosis Pemupukan Organik}

Hasil terbaik pada penelitian dengan menggunakan berbagai dosis pupuk Tithonia adalah dosis 180 $\mathrm{kgN} \mathrm{ha}^{-1}$. Di mana pada T4 tersedia nutrisi yang tinggi dibanding dosis Tithonia lainnya. Kandungan mineral $\mathrm{N}$ di tanah untuk perlakuan T4 35\% lebih tinggi dibandingkan dosis Tithonia yang lain. Luas daun tanaman okra pada perlakuan dosis Tithonia T4 35\% lebih tinggi dibandingkan dosis Tithonia yang lain. Bobot kering bagian tanaman di atas tanah untuk perlakuan T4 $31 \%$ lebih tinggi dibandingkan dosis Tithonia yang lain. Pada variabel bobot polong didapatkan bahwa perlakuan T4 menghasilkan bobot polong $66 \%$ lebih tinggi dibandingkan dosis Tithonia yang 
lain. Daun ialah bagian tanaman yang berfungsi sebagai organ fotosintesa. Menurut Green (2013) bahwa daun ialah suatu ukuran yang dapat membantu menentukan investasi produksi suatu tanaman yang sangat penting untuk proses pertumbuhan tanaman.

\section{Pertumbuhan dan Hasil Tanaman Okra pada Perlakuan Pemulsaan dan Tanpa Mulsa}

Pemulsaan menurunkan nilai rata-rata jumlah total polong per hektar dan bobot segar polong masing masing $26 \%$ dan $48 \%$ dibandingkan tanpa pemberian mulsa (Tabel 2). Demikian juga serapan $\mathrm{N}$ pada perlakuan tanpa mulsa lebih tinggi $32 \%$ dibandingkan perlakuan pemulsaan. Serapan P lebih tinggi 30\% pada perlakuan tanpa mulsa dibandingkan perlakuan pemulsaan. Sedangkan serapan $\mathrm{K}$ pada perlakuan tanpa pemulsaaan lebih tinggi $37 \%$ dibandingkan perlakuan pemulsaan.

Pada perlakuan pemulsaan terjadi penurunan $\mathrm{pH}$ tanah baik pada umur tanaman 60 HST dan 100 HST. Pada umur $60 \mathrm{HST}$ pH tanah untuk perlakuan pemulsaan turun dari 6,4 menjadi 6,2. Pada akhir pengamatan $\mathrm{pH}$ turun 0,3 poin dari 6,5 menjadi 6,2. Penurunan $\mathrm{pH}$ tanah pada perlakuan pemulsaan disebabkan terjadinya proses dekomposisi secara anaerob (keadaan kurang $\mathrm{O}_{2}$ ) yang melibatkan bakteri heteretrof. Pada proses ini terjadi pembentukan sulfat dan methane yang akan menyumbang $\mathrm{H}^{+}$bagi tanah yang menyebabkan penurunan $\mathrm{pH}$. Pada suasana yang lebih asam maka bakteri nitrifikasi akan lebih lambat mobilitas dalam proses dekomposisi bahan organik. Menurut Matthies, et al. (1997) optimum untuk proses dekomposisi adalah 6,5-8,0 pada kondisi demikian bakteri dan jamur akan lebih aktif dibandingkan pada kondisi masam. Dari penelitian yang dilakukan oleh Makus, et al., (1994) pada tanaman okra yang diberikan pemulsaan organik menggunakan daun pinus (Pinus taeda L.) di Lorman, Mississippi pada tanah liat berlempung memberikan hasil polong okra yang lebih rendah dibandingkan perlakuan tanpa mulsa (bare soil), baik hasil $\left(\right.$ tha $\left.^{-1}\right)$ maupun jumlah polong per hektar. Dari hasil penelitian tersebut dikatakan bahwa terjadi penurunan pH dari 6,72 menjadi 6,15 untuk 
perlakuan pemulsaan. Penurunan $\mathrm{pH}$ menyebabkan terganggunya proses dekomposisi bahan organik. Pemberian mulsa pada musim hujan yang semula diharapkan akan menekan terjadinya longsor pada gulud yang menyebabkan hilangnya tanah yang membawa serta bahan organik tetapi ada faktor lain sehingga tujuan tersebut tidak tercapai. Dari hasil pengamatan selama penelitian terhadap suhu tanah diperoleh hasil bahwa pemulsaan menurunkan suhu tanah 2 poin (dari $26^{\circ} \mathrm{C}$ menjadi $24^{\circ} \mathrm{C}$ ) pada siang hari dan 1 poin (dari $25^{\circ} \mathrm{C}$ menjadi $24^{\circ} \mathrm{C}$ ) pada pagi hari. Keadaan yang demikian sangat mempengaruhi proses dekomposisi bahan organik. Menurut Sumaryati (2014) bahwa mulsa di permukaan tanah akan menjerap radiasi matahari dan menurunkan suhu tanah. Penelitian yang sama dilakukan oleh Damanik (2010), bahwa penggunaan mulsa organik jerami padi pada tanaman kacang tanah jagung dengan mulsa jerami dapat menurunkan suhu tanah dan menurunkan laju dekomposisi.

\section{KESIMPULAN DAN SARAN}

\section{Kesimpulan}

Pemupukan optimal diperoleh pada dosis $180 \mathrm{~kg} \mathrm{Nha}^{-1}$ Tithonia atau setara 7 tonha $^{-1}$ Tithonia yang menghasilkan rata-rata bobot kering tanaman total 90-200\% lebih tinggi dan bobot polong okra $41 \%$ lebih tinggi dibandingkan dosis Tithonia yang lain.

Pemulsaan jerami padi berpengaruh negatif pada tanaman semusim okra dan menurunkan jumlah polong 26-48\%. Bobot polong okra turun hingga $57-98 \%$ akibat pemulsaan jerami padi.

Bobot polong nyata meningkat sekitar $36 \%$ pada pemupukan anorganik dibandingkan organik Tithonia, dengan nilai 112, 38 tonha $^{-}$ 1 pada perlakuan anorganik terhadap 71.81 tonha $^{-1}$ pada pemupukan organik.

\section{Saran}

Untuk menghasilkan produk organik pada okra di lahan berbahan organik sedang (> 2\%) di musim hujan disarankan menggunakan Tithonia dengan dosis $180 \mathrm{kgNha}^{-1}$ atau setara 7 ton ha $^{-1}$ Tithonia. 


\section{DAFTAR PUSTAKA}

Afandi. N. F., B.Siswanto, Y. Nuraini. 2015. Pengaruh Pemberian Berbagai Jenis Bahan Organik Terhadap Sifat Kimia Tanah pada Pertumbuhan dan Produksi Tanaman Ubijalar di Entisol Ngrangkah Pawon Kediri. Jurnal Tanah dan Sumberdaya Lahan. 2 (2): 237-244.

Berek, A.K. 2017. Teh Kompos dan Pemanfaatannya sebagai Sumber Hara dan Agen Ketahanan Tanaman. J Savana Cendana. 2 (4): 68-70.

Damanik, B.S.D. 2010. Beberapa Sifat Fisik Tanah dan Laju Infiltrasi Pada Latosol Darmaga (Studi Pada Tanaman Kacang Tanah). Skripsi. IPB. Bogor.

Dewanti, D. 2005. Dosis Tithonia (Tithonia difersifolia) dan Tingkat Kerapatan pada Pertumbuhan dan Hasil Tanaman Kentang (Solanum tuberosum L.) Varietas Granola Bunga Ungu. Thesis. Pascasarjana. Unibraw. Malang.

Green, J.T. 2013. Principles of Plant Growth (Factors Which Affect Growth and Persistence of Plants and the Implications for Grazing) Management. Crop Science Department (Forages) North Carolina State University.

Matthies, C., H.P. Erhard, and H. Drake. 1997. Effects of $\mathrm{pH}$ on the comparative culturability of fungi and bacteria from acidic and less acidic forest soils. Article in Journal of Basic Microbiology 37 (5): 335-343.

Mwangi, P.M. and P.W. Mathenge. 2014. Comparison of Tithonia (Tithonia diversifolia L Moench), Green Manure, Poultry manure and Inorganic Sources of Nitrogen in the Growth of Kales (Brassica oleraceae) in Nyeri County, Kenya. J African of Food, Agriculture, Nutritio and Development. 13 (14).

Utami, S.R., K. Hairiah, Supriyadi, M. van Noordwijk. 2005. Pemanfaatan Bahan organik Insitu (Tithonia difersifolia dan Tephrosia candida): MeningkatkanKetersediaan Fosfor Pada Andisol.Hasil Penelitian Kerjasama Jurusan Tanah Unibraw dengan ICRAF. Unpublished.

Sumaryati. 2014. Respon Perubahan Temperatur Permukaan terhadap Energi Radiasi Matahari. Prosiding Pertemuan Ilmiah XXVIII HFI Jateng \& DIY, Yogyakarta, 26 April 2014. ISSN: 0853-0823.

Zulkarnain, M., B. Prasetya, Soemarno. 2013. Pengaruh Kompos, Pupuk Kandang, dan Custom-Bio terhadap Sifat Tanah, Pertumbuhan dan Hasil Tebu (Saccharum officinarum L.) pada Entisol di Kebun Ngrangkah-Pawon, Kediri. Indonesian Green Technology Journal. 2 (1). 